\section{Carbon emission reduction potentials through thinned wood in Japan}

\author{
Etoh H, Sasaki N, Chay S, Ninomiya H
}

Substituting fossil fuel with woody biomass for bioelectricity production has great potentials for carbon emission reductions while increasing forest productivity to increase carbon sequestration and improve ecological functionalities. Until recently, study on such potentials was very limited. Beginning in 2007, Japan's special budgets were allocated for a 6-year intensive thinning on about 3.3 million ha of young stands for increasing carbon sinks in Japanese forests to meet the capped amount of $47.7 \mathrm{Tg} \mathrm{CO}_{2}$ year $^{-1}$ allowed under the Marrakesh Accord. Because of only $30 \%$ of the thinned wood were used for sawntimber, $\mathrm{CO}_{2}$ and $\mathrm{CH}_{4}$ must have been emitted from the disposed thinned wood and wood waste. Such emissions and reduction potentials need to be assessed to provide future alternatives for climate change mitigation. We assessed carbon emission reduction potentials when woody biomass from thinned wood is fully utilized for bioelectricity production as compared with the generation of the same amount of energy produced under coal, oil, and natural gas scenarios. Our analytical results show that if all disposed thinned wood and wood waste are utilized to generate energy, about $62.6,58.3$, and $37.8 \mathrm{Tg} \mathrm{CO}_{2}$ year $^{-1}$ could be prevented from emitting depending on emission scenarios or about $33.2,30.9$, and $20.0 \%$ of Japan's reduction commitment to the Kyoto Protocol. On the other hand, if thinned wood and wood waste are not utilized, about $13.4 \mathrm{Tg} \mathrm{CO}_{2}$ year $^{-1}$ would be released due to thinning. Our results suggest that incentives to reducing emission reductions in forest sector in the future climate change mitigation agreements will likely lead to large emission reductions, otherwise leakages due to thinning are unavoidable.

Keywords: Bioenergy policy, Carbon sinks, Disposed thinned wood, Thinning, Woody biomass

\section{Introduction}

Japan is a signatory country to the Kyoto Protocol of the United Nations Framework Convention on Climate Change (UNFCCC) Like other signatory countries, Japan is required to reduce greenhouse gas emissions. Japan's greenhouse gas reduction target for the first commitment period of the Kyoto Protocol (2008-2012) is 6\% below the 1990 baseline level. However, as greenhouse gas emissions continued to increase to 1.374 million tons $\mathrm{CO}_{2}$ in 2007 ( 1 million tons

Graduate School of Applied Informatics, University of Hyogo, 7-1-28-6F Minatojimaminamimachi, Chuo-ku, Kobe 650-0047 (Japan)

@ Nophea Sasaki (nop.kankyo@ai.uhyogo.ac.jp)

Received: Oct 08, 2010 - Accepted: Mar 29, 2011

Citation: Etoh H, Sasaki N, Chay S, Ninomiya $\mathrm{H}, 2011$. Carbon emission reduction potentials through thinned wood in Japan. iForest 4: 107-112 [online 2011-06-01] URL: http://www.sisef.it/iforest/show.php? id $=574$
$\mathrm{CO}_{2}=1 \mathrm{Tg} \mathrm{CO}_{2}$ ), an increase of $8.7 \%$ from the 1990 baseline level, Japan is therefore required to reduce $14.7 \%$ below the current level (Ministry of Environment 2009a) in order to fulfill its reduction commitment. In meeting reduction commitment, several reduction options are allowed under the protocol. One of the options is the enhancement of carbon sinks through forest management, which was agreed in the Marrakesh Accord in 2001 (UNFCCC 2002). Japan has selected to use forest carbon sinks option for meeting its reduction commitment to the Kyoto Protocol (2008-2012). Carbon sinks from forest management in Japan are capped at $47.7 \mathrm{Tg}$ $\mathrm{CO}_{2}$ year $^{-1}$ or $3.9 \%$ of the $6 \%$ reduction committed by Japanese government. However, recent studies suggested that carbon sinks in Japanese forests could unlikely reach that capped amount (Sasaki \& Kim 2009, Matsumoto 2008) if intensive thinning to accelerate forest growth is not implemented. Foreseeing this shortfall, Japanese Forestry Agency implemented special additional thinning activities on 0.20 million ha of forest area in addition to regular thinning of 0.35 million ha year-1. With this additional area for thinning, altogether 0.55 million ha year ${ }^{-1}$ or 3.3 million ha of young stands are thinned over a 6-year period beginning in 2007 (Forestry Agency 2008b). Special budget for this additional thinning ( 0.20 million ha) was 76.5 billion yen in 2007, 54.6 billion yen in 2008, and 62.0 billion yen in 2009 . On average, the special budget for additional thinning activities is 64.34 billion yen year ${ }^{-1}$ (US\$ 769.9 million at a current rate of US\$ $1=83.57$ yen) for thinning 0.20 million ha or about 321700 yen ha $^{-1}$ (\$ 3 849.57). More budgets are also expected for another 3 years, but information is not yet available.

Because only $30 \%$ of the thinned wood (personal communications with Forestry Agency officer) are generally used for producing sawnwood, the remaining $70 \%$ of the thinned wood (disposed thinned wood hereafter) and wood waste (the latter is accumulated at the sawmills when thinned wood is further processed for sawnwood) are left behind in the forests and at the sawmills, respectively. As such disposed thinned wood and wood waste gradually emit greenhouse gases such methane and $\mathrm{CO}_{2}$ (Yamazaki 2009, Gardner et al. 1993, Jones et al. 2010), alternative use of this disposed thinned wood and associated wood wastes such as for the use as biomass to substitute the use of fossil fuel for power generation should be explored or, in the long run, carbon emissions from thinning cannot be avoided. Although the current accounting rules for the Kyoto agreement include emission reductions in energy, transport, and industrial sectors, carbon emission reduction potentials due to thinning activities in forest sector need to be explicitly assessed for better informed decision making. Thinned wood and wood waste are important source of woody biomass for bioenergy production. Using woody biomass from thinned materials and logging residues is an important energy management consideration (Kinoshita et al. 2009, Sasaki et al. 2009) and could contribute to reducing the amount of greenhouse gases emissions ( $\mathrm{Sa}$ saki et al. 2009). In this paper, we assess the potential woody biomass available from the Forestry Agency's 6-year management plan for bioelectricity production and compare potential emission reductions if woody biomass is substituted for coal, oil, or natural gas in the production of electricity. We also examine policies for promoting woody biomass utilization in Japan. The paper is structured as follow: (1) woody biomass available from thinning and related wood processing is analyzed, wood bioenergy is estimated; carbon emission reduction potentials are compared against three scenarios of using coal, oil, and natural gas for the same amount of energy generated from the burning of woody biomass; and (2) bioenergy policy for promoting the utilization of woody biomass is discussed. 


\section{Materials and Methods}

\section{Forests in Japan}

In 2007, Japan has a total forest area of 25.1 million ha or about $66.4 \%$ of the country's total land area (Forestry Agency 2009). Area of plantation forests accounts for $42.2 \%$ of the total forest area followed by $53.3 \%$ natural forests, and $4 \%$ bamboo and other forests. Approximately $97 \%$ of the planted species are coniferous tree species such as Sugi (Japanese cedar, Cryptomeria japonica), Hinoki (Japanese cypress, Chamaecyparis obtusa), Karamatsu (Japanese Larch, Larix kaempferi), Todomatsu (Sakhalin fir, Abies sachalinensis), and Ezomatsu (Jezo Spruce, Picea jezoensis). Of the 10.1 million ha of plantation forests, Sugi, Hinoki, Karamatsu, and Todomatsu cover about $44.8 \%, 25.8 \%, 10.2 \%$, and $7.8 \%$, respectively. About $65.0 \%$ of plantation forests are owned by private companies or individuals, $22.8 \%$ are owned by the central government under the jurisdiction of the forestry agency, and the rest are mostly owned by local governments such as prefectures and districts. For natural forests, about $53.9 \%$ are owned by private companies or individuals, $35.1 \%$ are owned by the central government, and the rest are owned by local governments. Due to the decline of domestic timber price since 1990s (Ota 2010), many plantation forests are left unmanaged, especially privately owned forests even if the majority of the forests reach the ages for thinning to accelerate the growth and yield. Currently, approximately $60-80 \%$ of the plantation forests under age classes of 4 through 15 (one age class is 5 years - Tab. 1) require immediate thinning (MAFF 2010), but such thinning activities are impossible without government subsidies. In recent years, Japanese government through its forestry agency has increasingly promoted and provided subsidies for thinning the forests for achieving maximum carbon sinks as well as improving the ecological and environmental functions of the forests.

\section{Data Sources}

Data on standing stocks and forest areas by age classes of young stands to be thinned were obtained from forestry statistics published by the Forestry Agency (2008a).

\section{Data Analysis}

There are three categories of woody biomass in this paper, namely woody biomass from disposed thinned wood, that of branches and top logs of used thinned wood, and that of wood waste created by the processing of thinned wood at the sawmills. To estimate the amount of woody biomass available from thinning activities, we needed to obtain the amount of wood thinned during the 6-year period. The average of thinned wood,

Tab. 1 - Stand volume (SV), area (SA), Thinning ratio (R), amount of thinned wood (TW), and amount of thinned wood used to produce sawn wood (TWS) by age class. $(*)$ : Thinning ratio (R) is taken from Ejiri (1990). Stand volume and forest area are obtained from the Forestry Agency (2008a).

\begin{tabular}{cccccc}
\hline Class age & $\begin{array}{c}\text { Volume }\left(\mathbf{m}^{3}\right) \\
\left(\boldsymbol{S}_{\mathbf{i}}\right)\end{array}$ & $\begin{array}{c}\text { Area (ha) } \\
\left(\boldsymbol{S} \boldsymbol{A}_{\mathbf{i}}\right)\end{array}$ & $\begin{array}{c}\text { Thinning } \\
\text { ratio*(r) } \\
(\mathbf{\%})\end{array}$ & $\begin{array}{c}\text { Volume/ } \\
\text { Area } \cdot \mathbf{r} \\
\left(\boldsymbol{T} \boldsymbol{W}_{\mathbf{i}}\right)\end{array}$ & $\begin{array}{c}\text { Usable wood } \\
\left(\boldsymbol{T} \boldsymbol{W}_{\mathrm{i}} \cdot \mathbf{0 . 3}\right) \\
\left(\boldsymbol{T} \boldsymbol{W} \boldsymbol{S}_{\mathbf{i}}\right)\end{array}$ \\
\hline 4 & 46388000 & 589367 & 20 & 15.7 & 4.7 \\
5 & 107306000 & 873569 & 20 & 24.6 & 7.4 \\
6 & 194336000 & 1148619 & 20 & 33.8 & 10.2 \\
7 & 343437000 & 1599210 & 20 & 43.0 & 12.9 \\
8 & 421953000 & 1677145 & 20 & 50.3 & 15.1 \\
9 & 432575000 & 1522285 & 20 & 56.8 & 17.0 \\
10 & 297908000 & 945725 & 20 & 63.0 & 18.9 \\
11 & 122472000 & 353408 & 20 & 69.3 & 20.8 \\
12 & 76444000 & 203756 & 20 & 75.0 & 22.5 \\
13 & 64652000 & 171243 & 20 & 75.5 & 22.7 \\
14 & 54439000 & 143549 & 20 & 75.8 & 22.8 \\
15 & 43714000 & 111831 & 20 & 78.2 & 23.5 \\
Weighted Average $(T W$ in eqn. 1$)$ & & 42.2 & 14.2 \\
\hline
\end{tabular}

thinned available for woody biomass production, and thinned wood used for producing sawnwood can be estimated by the following equations (eqn. 1 , eqn. 2 , eqn. 3 , respectively):

$$
\begin{gathered}
T W=\frac{\sum_{i=1}^{15} S V_{i}}{\sum_{i=1}^{15} S A_{i}} \\
T W B=T W \cdot(1-0.3) \\
T W S=T W-T W B
\end{gathered}
$$

where $T W$ is the average volume of all thinned stands for all age classes $\left(\mathrm{m}^{3} \mathrm{ha}^{-1}\right.$ year $\left.{ }^{-1}\right) ; S V_{\mathrm{i}}$ is the total stand volume corresponding to age class $i\left(I=4-15 ; \mathrm{m}^{3}\right) . S A_{\mathrm{i}}$ is the total area of thinned stands in age class $i$; and $r$ is the thinning rate. Due to the lack of information for thinning rate for individual age classes for the entire country, $r$ was assumed to be $20 \%$ of stand volume $(r=0.2)$ based on Ejiri (1990). TWB is the amount of thinned wood available as woody biomass for bioelectricity production $\left(\mathrm{m}^{3} \mathrm{ha}^{-1}\right)$. TWS is the amount of thinned wood processed to produce sawn wood products $\left(\mathrm{m}^{3} \mathrm{ha}^{-1}-\mathrm{Tab}\right.$. 1). According to the Forestry Agency (personal communications), $30 \%$ of the thinned wood is processed for use as sawn wood products and the remaining $70 \%$ is left in the forests. Therefore, 0.3 is used as the proportion in eqn. 2 and eqn. 3.

Potential woody biomass $(B M)$ for the 6year period was estimated as follows (eqn. $4)$ :

$$
\begin{aligned}
B M= & \{(T W B \cdot W D \cdot B E F) \\
& +[T W S \cdot W D \cdot(B E F-1)] \\
& +[T W S \cdot W D \cdot(1-a)]\} \cdot T A
\end{aligned}
$$

where $B M$ is the total potential woody biomass for the period (Tg); WD is wood density $\left(W D=0.369 \mathrm{Mg} \mathrm{m}^{-3}\right.$, based on the weighted average of wood density of Sugi (0.314), Hinoki (0.407), Karamatsu (0.404), Todomatsu (0.319), Ezomatsu (0.348), and other coniferous trees $(0.423)$ reported in the National Greenhouse Gas Inventory Report of Japan (GIO/CGER 2010); BEF is the biomass expansion factor $(B E F=1.5$ - NIES 2007); $B E F-1$ is the proportion of branches and top logs left in the forests (in the case, when thinned wood is exported to sawmills for sawnwood producing); $T A$ is the total thinned area for the period (million ha); and $a$ is the wood processing efficiency rate for sawn wood production $(a=0.65$ Yoshimoto \& Marušák 2007). Note that $\{(T W B \cdot W D \cdot B E F)\} \cdot T A$ is woody biomass from disposed thinned wood, $\{(T W S \cdot W D$. $(B E F-1)]\} \cdot T A$ is branches and top logs of used thinned wood, $\{(T W S \cdot W D \cdot(1-a)]\}$. $T A$ is wood waste at the sawmill.

Wood bioenergy from the utilization of woody biomass can be calculated as (eqn. 5):

$$
B E=B M \cdot 20
$$

where $B E$ is the amount of bioenergy produced from the total woody biomass (PJ). According to Hall (1997) and Sasaki et al. (2009), 1 Tg of biomass can generate 20 PJ of bioenergy, so a factor of 20 was used in eqn. 5 .

The corresponding carbon emissions were calculated as follows for the equivalent amounts of energy produced under coal, oil, and natural gas scenarios (eqn. 6):

$$
E S_{i}=B E \cdot S_{i}
$$

where $E S_{\mathrm{i}}$ is the amount of carbon emissions 
Tab. 2 - Conversion factors used in our study.

\begin{tabular}{|c|c|c|c|}
\hline Factor & Equation & Value & References \\
\hline Wood density $(W D)\left(\mathrm{Tg} \mathrm{m}^{-3}\right)$ & (4) & 0.3372 & Yoshimoto \& Marušák (2007) \\
\hline Biomass expansion factor $(B E F)$ & (4) & 1.5 & NIES (2007) \\
\hline Sawn processing efficiency $(a)$ & (4) & 0.65 & Yoshimoto \& Marušák (2007) \\
\hline Energy content in woody biomass $\left(\mathrm{PJ} \mathrm{Tg}^{-1}\right)$ & $(5)$ & 20 & Sasaki et al. (2009), Hall (1997) \\
\hline Emissions from burning coal $\left(\mathrm{Tg} \mathrm{CO}_{2} \mathrm{PJ}^{-1}\right)$ & (6) & 0.265 & Fridleifsson et al. (2008) \\
\hline Emissions from burning oil $\left(\mathrm{Tg} \mathrm{CO}_{2} \mathrm{PJ}^{-1}\right)$ & (6) & 0.248 & Fridleifsson et al. (2008) \\
\hline Emissions from burning natural gas $\left(\mathrm{Tg} \mathrm{CO}_{2} \mathrm{PJ}^{-1}\right)$ & (6) & 0.166 & Fridleifsson et al. (2008) \\
\hline Emissions from burning biomass $\left(\mathrm{Tg} \mathrm{CO}_{2} \mathrm{PJ}^{-1}\right)$ & (7) & 0.014 & Lancashire County Council (2010) \\
\hline Methane to $\mathrm{CO}_{2}$ conversion $\left(\mathrm{Tg} \mathrm{CO} \mathrm{TgCH}_{4}^{-1}\right)$ & $(11)$ & 21 & Primary Power International (2004) \\
\hline $\mathrm{CO}_{2}$ emissions from disposed wood, branches, and wood waste $(\mathrm{Tg} \mathrm{CO})_{2}$ & $(11)$ & 1.04808 & Jones et al. (2010) \\
\hline Methane emissions from disposed wood, branches, and wood waste $\left(\mathrm{Tg} \mathrm{CH}_{4}\right)$ & (11) & 0.0113 & Jones et al. (2010) \\
\hline
\end{tabular}

for each scenario $i\left(\mathrm{Tg} \mathrm{CO}_{2}\right) ; S_{\mathrm{i}}$ is the emission factor of $i$-th scenario $(i=$ coal, oil, gas). According to Fridleifsson et al. (2008), $S_{\text {coal }}$ is $0.265 \mathrm{Tg} \mathrm{CO}_{2} \mathrm{PJ}^{-1}, S_{\text {oil }}$ is $0.248 \mathrm{Tg}$ $\mathrm{CO}_{2} \mathrm{PJ}^{-1}$, and $S_{\text {gas }}$ is $0.166 \mathrm{Tg} \mathrm{CO}_{2} \mathrm{PJ}^{-1}$ (Tab. 2).

By assuming that emission reductions due to thinning in forest sector (excluded landfills in the dump sites, which is already accounted in the Kyoto Protocol) are also included in the climate change mitigation agreement, then we can calculate the carbon emission reduction potential $(R P)$ for the first commitment period of the Kyoto Protocol for each scenario using the following equation (eqn. 7)

$$
R P_{i}=\frac{\left(E S_{i}-P E\right)}{(6 \cdot J C)} \cdot 100
$$

where $R P_{\mathrm{i}}$ is the emissions reduction potential for each scenario (\%); $E S_{\mathrm{i}}$ is the amount of emissions under the $i$-th scenario $(\mathrm{Tg}$ $\mathrm{CO}_{2}$ ); $P E$ is the bioenergy production emissions produced as a result of the thinning process and the use of woody biomass as fuel $\left(\mathrm{Tg} \mathrm{CO}_{2}\right)$; and $J C$ is Japan's Kyoto Protocol emission reduction commitment of $13.7 \%$ below the baseline 1990 emissions (compared to emission level in 2007) for 2008-2012 ( $\mathrm{Tg} \mathrm{CO}_{2}$ year $\left.^{-1}\right)$.

$P E$ in eqn. 7 can be derived as follows (eqn. 8):

$$
P E=2 \cdot T E \cdot T A+b \cdot B E
$$

where $T E$ is the amount of emissions produced from thinning activities $\left(\mathrm{Tg} \mathrm{CO}_{2}\right)$, and $b$ is the emissions factor from burning biomass $\left(b=0.014 \mathrm{Tg} \mathrm{CO}_{2} \mathrm{PJ}^{-1}\right.$ - Lancashire County Council 2010). Due to lack of data, transport emissions were assumed to be equal to $T E$.

$T E$ in eqn. 8 is derived as follows (eqn. 9):

$$
T E=G S \cdot G C
$$

where $G S$ is the amount of fuel consumed in thinning 1 ha of forest $\left(G S=921\right.$ ha $^{-1}$ (Tottori Prefecture 2008), and $G C$ is the amount of carbon dioxide emitted in burning 1 of gasoline $\left(G C=0.00235 \mathrm{MgCO} 2 \mathrm{l}^{-1}\right)$.

$J C$ in eqn. 7 was calculated as follows (eqn. 10):

$$
J C=E_{2007}-E_{1990} \cdot(1-0.06)
$$

where $E_{2007}$ is Japan's latest emissions (reported in 2007: $1.374 \mathrm{Tg} \mathrm{CO}_{2}$ - Ministry of Environment 2009b), and $E_{1990}$ is the baseline 1990 emissions (1.261 Tg CO Ministry of Environment 2009b). The reduction commitment in the Kyoto Protocol adopted in 1997 was $6 \%$ or 0.06 .

On the other hand, if woody biomass is not utilized to substitute fossil fuel for bioelectricity production, all disposed thinned wood and wood waste from thinning activities will emit methane and carbon dioxide as they start to decay. Methane and carbon emissions from disposed thinned wood and wood waste were estimated as follows (eqn. 11)

$$
\mathrm{AE}=\mathrm{BM} \cdot\left(\mathrm{CH}_{4} \cdot+\mathrm{CO}_{2}\right)
$$

The emission factors for the waste of disposed thinned wood, branches, and wood waste from processing are $\mathrm{CH}_{4}=0.00113$ $\mathrm{Mg} \mathrm{CH} \mathrm{Mg}^{-1}$ for methane and $\mathrm{CO}_{2}=$ $1.04808 \mathrm{Mg} \mathrm{CO}_{2} \mathrm{Mg}^{-1}$ for $\mathrm{CO}_{2}$ (Jones et al. 2010 ), and the $\mathrm{CH}_{4}$ emission conversion factor to $\mathrm{CO}_{2}$ is 21 .

\section{Results}

The average volume of all thinned wood from the stands was calculated to be $47.2 \mathrm{~m}^{3}$

\begin{tabular}{|c|c|c|c|}
\hline \multirow[b]{2}{*}{ Burning } & \multicolumn{2}{|c|}{ Reduction potential $\left(\mathrm{Tg} \mathrm{CO}_{2}\right)$} & \multirow{2}{*}{$\begin{array}{c}\text { Percentage of } \\
\text { reduction commitment } \\
\text { by Japan* } \\
(\%)\end{array}$} \\
\hline & Per 6 years & Per year & \\
\hline Compared coal burning & 375.3 & 62.6 & 33.2 \\
\hline Compared oil burning & 349.8 & 58.3 & 30.9 \\
\hline $\begin{array}{l}\text { Compared natural gas } \\
\text { burning }\end{array}$ & 226.7 & 37.8 & 20.0 \\
\hline
\end{tabular}

Tab. 3 - Emissions reduction potentials under each emission scenario. $(*)$ : Japan is committed to reduce $6.0 \%$ of the greenhouse gas emissions below the 1990 level (baseline). As emissions continue to increase to $8.7 \%$ more in 2007, Japan must reduce $188.7 \mathrm{Tg} \mathrm{CO}_{2}$ year $^{-1}$ $(6.0+8.7=14.7 \%)$ in order to fulfill its Kyoto commitment. $\mathrm{ha}^{-1}$, of which $33.1 \mathrm{~m}^{3} \mathrm{ha}^{-1}(70 \%)$ is wood available as woody biomass for bioelectricity production and $14.2 \mathrm{~m}^{3} \mathrm{ha}^{-1}$ is wood available to produce sawn wood. The total potential woody biomass was estimated to be 68.6 Tg from the thinning of 3.30 million ha of young stands over the 6-year period. Of the $68.6 \mathrm{Tg}, 55.2 \%, 7.9 \%$, and $5.5 \%$ are that of disposed thinned wood, branches and top logs, and wood waste at the sawmills, respectively. If all this biomass is utilized for bioenergy production, about $1371.7 \mathrm{PJ}$ or 228.6 PJ year ${ }^{-1}$ can be generated from burning the woody biomass, which would account for $2.3 \%$ of the total production of electricity in Japan $(9760.6 \mathrm{PJ})$ in 2006 (FEPC 2010)

The three emission reduction scenarios were also examined, in which coal, oil, and natural gas were burned to produce the same amount of electricity (602.5 PJ). After deducting production emissions due to thinning 20.6 $\mathrm{Tg} \mathrm{CO}_{2}$, total reductions for the 6year period were about $375.3,349.8$, and $226.7 \mathrm{Tg} \mathrm{CO}_{2}$ for coal, oil, and natural gas scenarios, respectively, or about $62.6,58.3$, and $37.8 \mathrm{Tg} \mathrm{CO}_{2}$ year $^{-1}$. These emission reduction potentials account for $33.2 \%$, $30.9 \%$, and $20.0 \%$ of Japan's annual reduction commitment of $188.7 \mathrm{Tg} \mathrm{CO}_{2}$ (using 2007 data), when woody biomass substitutes for coal, oil, and natural gas, respectively, in the production of electricity (Tab. 3). Although there are large emission reductions 
Tab. 4 - Published unit purchase prices of biomass-generated electricity for 10 Japanese electric power companies. Prices are reported as yen $\mathrm{kWh}^{-1}$.

\begin{tabular}{|c|c|c|c|c|c|}
\hline $\begin{array}{l}\text { Electric Power } \\
\text { Company }\end{array}$ & Energy source & $\begin{array}{c}\text { Summer season }(7 / 1-9 / 30) \text { or } \\
\text { Winter season }(12 / 1-2 / \text { end }) \\
\text { Week day }(8: 00-22: 00)\end{array}$ & $\begin{array}{l}\text { Other } \\
\text { time }\end{array}$ & $\begin{array}{c}\text { Week day of } \\
\text { other seasons } \\
(8: 00-22: 00)\end{array}$ & $\begin{array}{l}\text { Other } \\
\text { time }\end{array}$ \\
\hline $\begin{array}{l}\text { Hokkaido Electric Power } \\
\text { Company (2009) }\end{array}$ & $\begin{array}{l}\text { New energy authorization } \\
\text { power supply }\end{array}$ & 4.50 (Winter season) & 2.70 & 4.00 & 2.70 \\
\hline $\begin{array}{l}\text { Tohoku Electric Power } \\
\text { Company (2007) }\end{array}$ & $\begin{array}{l}\text { New energy generation, } \\
\text { Biomass generation }\end{array}$ & 5.90 (Summer season) & 2.20 & 5.00 & 2.20 \\
\hline $\begin{array}{l}\text { Tokyo Electric Power } \\
\text { Company (2010) }\end{array}$ & New energy generation & 6.90 (Summer season) & 2.50 & 6.10 & 2.50 \\
\hline $\begin{array}{l}\text { Chubu Electric Power } \\
\text { Company }\end{array}$ & Waste generation & - & - & - & - \\
\hline $\begin{array}{l}\text { Hokuriku Electric Power } \\
\text { Company (2009) }\end{array}$ & $\begin{array}{l}\text { New energy authorization } \\
\text { power supply }\end{array}$ & 4.55 (All season) & 4.55 & 4.55 & 4.55 \\
\hline $\begin{array}{l}\text { Kansai Electric Power } \\
\text { Company (2009) }\end{array}$ & Biomass generation & 5.34 (All season) & 5.34 & 5.34 & 5.34 \\
\hline $\begin{array}{l}\text { Chugoku Electric Power } \\
\text { Company (2010) }\end{array}$ & Biomass generation & 6.30 (Summer season) & 3.26 & 5.78 & 3.26 \\
\hline $\begin{array}{l}\text { Shikoku Electric Power } \\
\text { Company (2010) }\end{array}$ & $\begin{array}{l}\text { New energy distributed } \\
\text { power supply }\end{array}$ & 6.80 (Summer season) & 3.20 & 6.00 & 3.20 \\
\hline $\begin{array}{l}\text { Kyushu Electric Power } \\
\text { Company (2008) }\end{array}$ & Biomass generation & 5.80 (Summer season) & 2.90 & 5.10 & 2.90 \\
\hline $\begin{array}{l}\text { Okinawa Electric Power } \\
\text { Company (2009) }\end{array}$ & Biomass generation & 5.28 (All season) & 5.28 & 5.28 & 5.28 \\
\hline Average & - & 5.71 & 3.55 & 5.24 & 3.55 \\
\hline Weighted Average & & 4.67 & - & - & - \\
\hline
\end{tabular}

from the used of thinned wood, the current accounting rules under the Kyoto protocol do not account for such emission reductions If not utilized, disposed thinned wood, branches, and wood wastes at wood processing mills result in emissions of about $70.4 \mathrm{Tg} \mathrm{CO} \mathrm{CO}_{2}$ equivalent or $13.4 \mathrm{Tg} \mathrm{CO}$ year $^{-1}$.

\section{Discussion}

Critical need for including forest sector's carbon emission reductions in the future climate agreement

Our results show that, depending on the emission scenario, substitution of woody biomass for fossil fuel for energy generation could potentially reduce carbon emissions by $37.8-62.6 \mathrm{Tg} \mathrm{CO}_{2}$ year $^{-1}$ or about 20.0 $33.2 \%$ of Japan's reduction commitment under the Kyoto Protocol. The utilization of disposed thinned wood and wood waste has huge potentials for emission reductions. On the other hand, large emissions can not be avoided if utilization of such wood and waste are not promoted. Worse yet, if emissions from disposed thinned wood and associated wood waste (excluding landfills in the dump sites) are counted in the current carbon accounting system, Japan needs to reduce more emissions in order to meet the reduction targets. The exclusion of carbon emission reductions due to thinning in forest sector in the current accounting rules of the Kyoto protocol may also contribute to the non-utilization of disposed thinned wood and wood waste in Japan. Nevertheless, as long as climate change mitigation is concerned, it is therefore critically important that future climate change mitigation agreements also include thinning-driven emission reductions from other sectors such as forest sector. Meanwhile, as long as thinning continues, Japan should promote the utilization of disposed thinned wood and wood waste, otherwise actual emission reductions will not be achieved.

Need of incentive and appropriate policies

As reported in previous studies, costs were the major obstacle for wood-based bioelectricity production in Japan. For instance, Ooki (2003) argued that expansion of bioelectricity production from thinned wood is financially infeasible. Endo (2006) reported that the costs for thinning, collecting, transporting and processing of thinned wood are high making it impossible to introduce wood-based bioelectricity production in Japan. As Japan is internationally required to reduce emissions, Japan needs to bear the responsibility for not compliance to the Kyoto agreement. As long as forests are thinned, wood residues (disposed thinned wood, branches, and wood wastes) need to be utilized in order to prevent unexpected emissions or leakages as a result of thinning to increase carbon sinks to reach the $3.9 \%$ capped amount. These leakages amount to $13.4 \mathrm{Tg}$
$\mathrm{CO}_{2}$ year $^{-1}$ or about $\$ 268$ million if carbon is priced at $\$ 20 \mathrm{MgCO}_{2}$ (carbon is priced at euro $15 \mathrm{Mg} \mathrm{CO}_{2}^{-1}$ at European market). The \$ 268 million is equivalent to $\$ 487.54 \mathrm{ha}^{-1}$ (about 40.466 yen) to be paid for any thinned forest in order to prevent thinning-driven leakages. This amount could be used as subsidies for promoting bioelectricity production in Japan.

In Yamaguchi prefecture where emission reduction is an urgent issue, wood-based biomass utilization is the most effective way, and therefore this prefecture has started cofiring coal and woody biomass since 2001 (Matsunaga \& Miura 2005). Matsunaga \& Miura (2005) suggest that cost issue can be addressed by maintaining demand for woody biomass from the forests and such demand can be achieved by utilizing woody biomass for bioelectricity production. According to annual report published by Japanese Forestry Agency in 2009 (Forestry Agency 2009), $77000 \mathrm{MgCO}_{2}$ of carbon credits were issued in 2008 to wood-based bioenergy producers. This latest development suggests that if appropriate incentive policies are introduced, wood-based bioenergy business could be expanded in Japan. Etoh \& Sasaki (2010) found that the lack of full-scale liberalization of the electricity market in Japan as well as a lack of fixed prices, taxation on fossil fuels, and an exemption from taxation on renewable energy sources (as is done in Europe) contribute to the general failure of the wood bioenergy business in Japan. Not having 
such policies creates an atmosphere in which the future supply of wood-based bioenergy is uncertain, there by making it difficult to predict the price of bioenergy or compare the price of producing bioenergy with producing energy from fossil fuels. Tab. 4 shows electricity purchase unit prices and weighted averages for 10 electric power companies throughout Japan. The weighted average unit price (this is the price that electric power companies pay bioenergy producers for power) of 4.6 yen $\mathrm{kWh}^{-1}$ is much less than the average of 18.0 yen $\mathrm{kWh}^{-1}$ in Germany (Souta 2007). This average is also very low as compared with the average of 22.1 yen $\mathrm{kWh}^{-1}$ for power generated from fossil fuels for households in Japan (Yamada 2002).

\section{Low price of bioenergy production}

It is difficult to make a profitable bioenergy from woody biomass in Japan because the unit price of electricity that the power companies are willing to pay for bioenergy producing companies is so low (NEDO 2010, Ooki 2003) because of the uncertainties of perpetual supplies of bioenergy, thereby making wood bioenergy producing companies often operate at a loss. In Japan, the Renewables Portfolio Standard imposed a purchase duty on the constant ratio of electricity by renewable energy in April 2003 enforced. The quantity of duty of 2010 is 12430 million kWh (METI 2009). However, positive introduction to promote utilization of woody biomass is difficult because the current policy does not support and favor producing bioenergy from woody biomass. In some European countries, the use of alternative energy sources, such as biofuels from woody biomass, has been effectively supported by preferential pricing of electricity produced by renewable energy sources, taxation of fossil fuels, and tax exemptions for renewable energy (Ericsson et al. 2004, Björheden 2006). Although the possible introduction of an environment-related taxation system was discussed in the Kyoto Protocol Accomplishment Plan (Cabinet Office 2008), no action has yet been taken. If such policies were introduced in Japan, the prices that producers are paid for bioenergy would be comparable to those for energy produced from burning fossil fuels, or perhaps even better as is the case in some European countries (Iida 2000). In addition, if the use of woody biomass to produce bioenergy becomes more economically feasible, thinning of forests for woody biomass would become a permanent business with many other benefits, including increased employment, healthier forests, reduced emissions, and other improved ecosystem functions.

\section{Conclusion}

Our results suggest that carbon emission reduction potentials are large in forest sector in Japan when thinning is carried out to increase carbon sinks to achieve the capped amount allowed under the Marrakesh Accord. The current thinning of 0.55 million ha between 2007 and 2012 would reduce 37.8 62.6 $\mathrm{Tg} \mathrm{CO}_{2}$ year $^{-1}$ or emit about $13.4 \mathrm{Tg}$ $\mathrm{CO}_{2}$ year ${ }^{-1}$ depending on whether or not the disposed thinned wood and wood waste are utilized. The exclusion of emission reductions in forest sector in the current accounting rules may have contributed to the nonutilization of wood biomass to substitute the use of high- $\mathrm{CO}_{2}$ emitting fossil fuel for electricity generation. Furthermore, as Japan recently pledged to reduce greenhouse gas emissions by $25 \%$ by 2020 (as compared to 1990 levels) at the Fifteenth Conference of the Parties (COP15) to the UNFCCC held in December 2009, the use of woody biomass to substitute the use of fossil fuels will continue to play a more important role in fulfilling Japan's post-Kyoto greenhouse gas emission reduction commitments. If appropriate wood bioenergy policies to utilize the thinning-driven wood residues are not introduced, and as long as emission reductions are concerned, thinning alone will not lead to actual net emissions as disposed wood residues will eventually emit $\mathrm{CO}_{2}, \mathrm{CH}_{4}$, and other minor greenhouse gases.

Japan needs to introduce appropriate policies as done or similar to that in some European countries such as the liberalization of the electricity market, fixed electrical price by renewable energy, renewable energy taxes. The utilization of woody biomass for energy production would therefore not only contribute to a reduction in greenhouse gas emissions and allow Japan to meet its reduction targets but would also play a role in sustainable forest management and the market for renewable energy. Existing policies, such as those in European countries that have developed markets for the use of woody biomass, should be examined in greater detail and analyzed in terms of how to best introduce and promote policies that encourage the use of woody biomass in Japan. Promoting the utilization of woody biomass from thinned wood is a win-win policy because thinning has multiple benefits including, but not limited to increasing carbon sinks in the forests, putting forestry business back to work, creating wood bioenergy as well as employment, putting more labor to work in forest sector to replace the ageing ones, and improving ecosystem functionalities as well as the continued flow of services from the well-functioning forest ecosystems.

\section{References}

Björheden R (2006). Drivers behind the development of forest energy in Sweden. Biomass and Bioenergy 30: 289-295. - doi: 10.1016/j.biombioe.2005.07.005

Cabinet Office (2008). For promoting the Kyoto protocol concerning the plan for attaining the target. Cabinet office, Government of Japan, Tokyo, Japan, pp. 1-10.

Chugoku Electric Power Company (2010). About the electricity purchase from new energy. Technical Report, The Chugoku Electric Power Co. Inc., Hiroshima, Japan.

Ejiri Y (1990). Decisions on optimal thinning by a recurring decision-making model. I. A maximization of total gains of stem volume. Journal of the Japanese Forestry Society 72 (4): 304-315.

Endo M (2006). The energy use of woody biomass - trend and problems. Investigation and information, Issue brief 510, National diet library, Japan, pp. 1-10.

Ericsson K, Huttunen S, Nilsson LJ, Svenningsson P (2004). Bioenergy policy and market development in Finland and Sweden. Energy Policy 32: 1707-1721. - doi: 10.1016/S0301-4215(03) 00161-7

Etoh H, Sasaki N (2010). Comparison of promotion policies for utilization of woody biomass between European countries and Japan. Journal of Japan Forest Society 92 (2): 88-92. - doi: $10.4005 /$ jjfs. 92.88

FEPC (2010). Electricity consumption in Japan. Technical Report, Federation of Electric Power Companies, Japan [in Japanese]. [online] URL: http://www.fepc.or.jp/present/jigyou/japan/index.html

Forestry Agency (2008a). Forest and forestry statistics handbook 2008. The Forestry Agency, Tokyo, Japan, pp. 8-11.

Forestry Agency (2008b). News of the beautiful forest management. Technical Report No.115, The Forestry Agency, Tokyo, Japan.

Forestry Agency (2009). Annual report on trends in forests and forestry fiscal year 2009. Technical Report, The Forestry Agency, Tokyo, Japan. Fridleifsson IB, Bertani R, Huenges E, Lund JW, Ragnarsson A, Rybach L (2008). The possible role and contribution of geothermal energy to the mitigation of climate change. In: "IPCC Scoping Meeting on Renewable Energy Sources". Luebeck (Germany) 21-25 January 2008, pp. 1-36. Gardner N, Manley BJW, Pearson JM (1993). Gas emissions from landfills and their contributions to global warming. Applied Energy 44: 165-174. - doi: 10.1016/0306-2619(93)90059-X

GIO/CGER (2010). National greenhouse gas inventory report of Japan. Greenhouse Gas Inventory Office of Japan (GIO), CGER, NIES, Ministry of Environment, Japan. [online] URL: http://www.gio.nies.go.jp/aboutghg/nir/2010/NI R_JPN_2010_v4.0E.pdf

Hall DO (1997). Biomass energy in industrialised countries - a view of the future. Forest Ecology Management 91: 17-45. - doi: 10.1016/S03781127(96)03883-2

Hokkaido Electric Power Company (2009). About the surplus electricity purchase (only as for the electricity) from new energy. Hokkaido Electric Power Co., Inc., Sapporo, Japan.

Hokuriku Electric Power Company (2009). About the electricity purchase from new energy generation. [online] URL: http://www.rikuden.co.jp/ 
konyu/newenergy.html

Iida T (2000). North European energy democracy. Shinhyoron Co. Ltd, Tokyo, pp. 90-118.

Jones G, Loeffler D, Calkin D, Chung W (2010).

Forest treatment residues for thermal energy compared with disposal by onsite burning: emissions and energy return. Biomass and Bioenergy: 34 (5): 737-746. - doi: 10.1016/j.biombioe.2010. 01.016

Kansai Electric Power Company (2009). About the electric value purchase from an RPS method object power supply. The Kansai Electric Power Co. Inc., Tokyo, Japan.

Kinoshita $\mathrm{T}$, Inoue $\mathrm{K}$, Iwao $\mathrm{K}$, Kagemoto $\mathrm{H}$, Yamagata Y (2009). A spatial evaluation of forest biomass usage using GIS. Applied Energy 86: 1-8. - doi: 10.1016/j.apenergy.2008.03.017

Kyushu Electric Power Company (2008). New energy guidance of the surplus electricity purchase from generation. Technical Report, Kyushu Electric Power Co. Inc., Fukuoka, Japan.

Lancashire County Council (2010). Wood fuel An environmental perspective. [online] URL: http://www.lancashire.gov.uk/corporate/web/vie wdoc.asp?id $=19558$

MAFF (2010). Forests and forestry restoration planning and policy. Ministry of Agriculture, Forestry and Fisheries, Japan [in Japanese]. [online] URL: http://www.maff.go.jp/j/budget/2010 3/pdf/sinrin.pdf

Matsumoto M (2008). Global warming and forests. Forest Science 52: 4-8. [online] URL: http://ci.nii.ac.jp/naid/110006633742

Matsunaga S, Miura S (2005). Total management approach to forest biomass utilization by local government in Yamaguchi Prefecture, Japan. Task 29 - Socio-Economic Drivers in Implementing Bioenergy Projects, IEA Bioenergy, Japan. [online] URL: http://www.task29.net/assets/ files/Case\%20Yamaguchi\%20Japan\%20rev2.pdf METI (2009). Target of the electric use by new energy about eight years after 2007. Ministry of Economy, Trade and Industry, Government of Japan, Tokio, Japan
Ministry of Environment (2009a). About greenhouse gas emissions in 2007. Technical Report, Ministry of Environment, Government of Japan [in Japanese]. [online] URL: http://www.env.go.jp/earth/ondanka/ghg/2007ghg.pdf

Ministry of Environment (2009b). National greenhouse gas inventory report of Japan. The Ministry of the Environment, Government of Japan, Tokio, Japan.

NEDO (2010). Biomass energy introduction guidebook ( $3^{\text {rd }}$ edn.). New Energy and Industrial Technology Development Organization - NEDO, Kawasaki, Japan, pp. 96-113 [in Japanese].

NIES (2007). National greenhouse gas Inventory Report of Japan 2007. National Institute for Environmental Studies, CGER-I076-2007, Ibaraki, pp. 7-8.

Okinawa Electric Power Company (2009). About the electricity purchase from new energy electricity generation. Technical Report, The Okinawa Electric Power Co. Inc., Japan. [online] URL: http://www.okiden.co.jp/corporate/purchase/outline.html

Ooki Y (2003). Problem investigation for woody biomass generation introduction (1). The Institute of Energy Economics, Tokyo, Japan, pp. 110.

Ota I (2010). Ecology-oriented house builders and FSC-certified domestic timber in Japan. Smallscale Forestry 9: 81-92. - doi: 10.1007/s11842009-9103-5

Primary Power International (2004). GHG reductions through offset of Canadian grid electricity and methane avoidance through waste wood diversion, pp. 2-11. [online] URL: http://www.ghgregistries.ca/files/projects/prj_3433_685.pdf

Sasaki N, Kim S (2009). Biomass carbon sinks in Japanese forests: 1966-2012. Forestry 82 (1): 113-123. - doi: 10.1093/forestry/cpn049

Sasaki N, Knorr W, Foster DR, Ninomiya H, Etoh H, Chay S, Kim S, Sun S (2009). Woody biomass and bioenergy potentials in Southeast Asia between 1990 and 2020. Applied Energy 86 (S1): S140-S150. - doi: 10.1016/j.apenergy.
2009.04.015

Shikoku Electric Power Company (2010). The Electricity purchase from new energy except the photovoltaic power generation. Technical Report, Shikoku Electric Power Co. Inc., Kagawa, Japan [in Japanese]. [online] URL: http://www.yonden.co.jp/energy/n_ene_kounyu/ pv_igai/index.html

Souta I (2007). Visit world's first biomass village Jühnde in Germany. V2-Solution Inc, Nagoya, pp. 2-20.

Tohoku Electric Power Company (2007). About new energy and the surplus electricity purchase from home generation of electricity. Tohoku Electric Power Co. Inc., Miyagi, Japan. [online] URL: http://www.tohoku-epco.co.jp/oshirase/ newene/02/pdf/06_2.pdf

Tokyo Electric Power Company (2010). About the electricity purchase from new energy generation. Tokyo Electric Power Company Inc., Tokyo, Japan. [online] URL: http://www.tepco.co.jp/erates/individual/shin-ene/pdf/shinene.pdf

Tottori Prefecture (2008). The budget of 2008 . Tottori Prefecture, Japan. [online] URL: http://tinyurl.com/3z839tk

UNFCCC (2002). Decision 14/CP.7. Report FCCC/CP/2001/13/Add.1, Conference of the Parties, $7^{\text {th }}$ Session. Marrakesh (Morocco) Oct 29 - Nov 10, 2001. United Nations Framework Convention on Climate Change (UNFCCC), pp. 5467.

Yamada T (2002). An international comparison of the electric unit price. The Institute of Energy Economics, Tokyo, Japan, pp. 1-10.

Yamazaki $\mathrm{M}$ (2009). $\mathrm{CO}_{2}$ reduction and trees, woods. News of Hokkaido forest products research institute. Forest Products Research Institute, Hokkaido, Japan, pp. 1-5.

Yoshimoto A, Marušák R (2007). Evaluation of carbon sequestration and thinning regimes within the optimization framework for forest stand management. Europen Journal of Forest Research 126: 315-329. - doi: 10.1007/s10342006-0150-6 